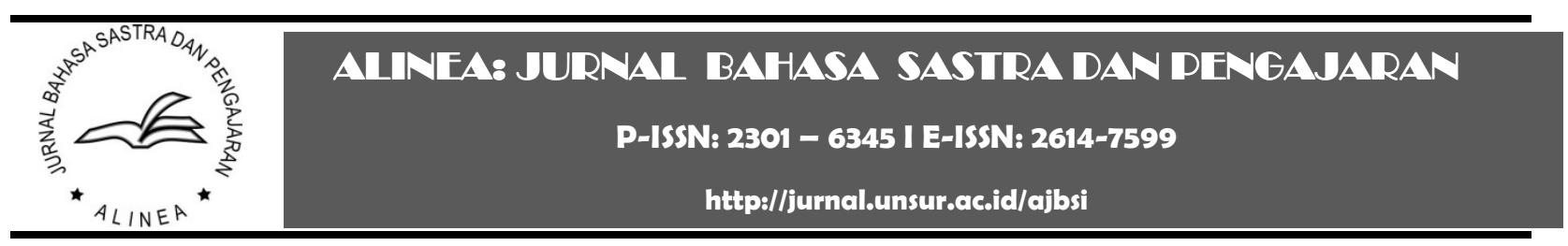

\title{
WACANA HUMOR DALAM BAJIGUR TV
}

\author{
Khoirul Anam, Rusdhianti Wuryaningrum, Ahmad Syukron \\ Universitas Jember, Indonesia
}

Riwayat artikel:

Dikirim: 3 Juli 2020

Direvisi: 15 Agustus 2020

Diterima: 15 Agustus 2020

Diterbitkan: 30 Oktober 2020

Katakunci:

anekdot, humor, teknik humor

Keywords:

anecdotes, humor, humor techniques

Alamat surat akhoirul687@gmail.com

\begin{abstract}
Abstrak:
Kajian dalam artikel ini terdiri atas empat rumusan yaitu bagaimanakah wujud wacana humor, bagaimanakah prinsip humor, bagaimanakah teknik humor, dan bagaimanakah pemanfaatan WHBTV untuk materi ajar menulis teks anekdot. Penelitian dilaksanakan menggunakan rancangan penelitian kualitatifetnografi berbahasa dengan pendekatan analisis wacana. Hasil yang ditemukan berwujud wacana ejekan terhadap pekerjaan, penyebab emosi, memanfaatkan kesusahan, tawaran mengecewakan, tipuan, menggoda wanita, melebihlebihkan hal sepele, memberikan alasan berubah-ubah, menjelaskan hal unik tidak masuk akal, olokan tertentu, dan dugaan salah. Prinsip humor pada wacana ini berupa prinsip kesepakatan berhumor, menggunakan tuturan yang berlebihan, penyampaian kritikan, dan menggunakan kata-kata brutal dalam batas kesopanan. Teknik humor dalam yang digunakan berupa bahasa yang menghasikan humor lewat kata-kata, logika memunculkan efek humor dari hasil pemikiran pemain, dan identitas berupa kekhasan berhumor pemain.
\end{abstract}

\begin{abstract}
:
The article discusses four research questions including how is the form, the principle and the technique of humour, and how the use of WHBTV for teaching materials to write anecdotal texts. The study was conducted using a qualitative-ethnographic language research design with a discourse analysis approach. The results were found in the form of discourses on ridicule of work, emotional causes, taking advantage of distress, disappointing offers, tricks, flirting with women, exaggerating trivial things, giving fluctuating reasons, explaining unique things that don't make sense, certain ridicule, and wrong allegations. The principle of humour in this discourse is in the form of the principle of agreement with humour, using excessive speech, conveying criticism, and using brutal words within the limits of politeness. The internal humour technique used is in the form of language that produces humour through words, logic creates a humorous effect from the results of the players' thoughts, and identity in the form of player humour.
\end{abstract}

\section{PENDAHULUAN}

Pentingnya pemahaman wujud humor yaitu untuk mengetahui bentuk-bentuk penyampaian humor agar tidak ada kesalahan tafsir terhadap sesuatu yang dimaksud. Penggunaan prinsip humor dipakai untuk memberikan pemahaman dalam menilai situasi humor. Penjelasan teknik humor diperlukan agar lawan tutur dapat mengetahui alasan mengapa seseorang memberikan respon senyum dan tertawa di saat menikmati humor.
Banyak persoalan serius yang disajikan secara rileks atau mudah dipahami dengan adanya humor. Hal tersebut disebabkan humor membuat sesuatu menjadi lebih santai sehingga dapat dipahami dan dapat menyelesaikan persoalan-persoalan yang serius. Sebagaimana pendapat Widyowati dan Priambodo humor dapat menjadikan lebih rileks, tidak tegang, sehingga pikiran pun dapat lebih berkonsentrasi untuk menyelesaikan masalah (Widyowati and Priambodo). Begitu pula pendapat Lestari dan Satrio yang menjelaskan bahwa penyampaian 
humor memiliki tujuan untuk mencairkan suasana (Lestari and Satrio). Oleh karena itu, dapat dikatakan humor dapat mencairkan suasana, sehingga membuat seseorang menjadi lebih tenang dan berpikir jernih sehingga dapat memahami dan menyelesaikan persoalan serius dengan tepat.

Humor yang memuat kritik sosial dapat digunakan sebagai sarana komunikasi yang berfungsi sebagai alat kontrol sosial. Kendati humor yang demikian masih menuai pro dan kontra. Sesuai dengan pernyataan Saptaningsih dan Sari humor dapat digunakan untuk membungkus kritik sosial yang banyak menuai pro dan kontra dan dapat dijadikan sebagai kontrol sosial dalam kehidupan bermasyarakat (Saptaningsih and Sari). Dengan demikian, dapat disimpulkan bahwa humor bisa menjadi alat kontrol sosial dalam masyarakat melalui kritik sosial yang terkandung dalam humor.

Humor dalam kehidupan masyarakat Indonesia sudah menjadi bagian dari budaya. Menurut pendapat Iskandar humor sudah menjadi bagian dari kesenian rakyat, seperti ludruk, ketoprak, lenong, wayang kulit, wayang golek, dan sebagainya (Iskandar). berdasarkan pendapat tersebut, humor tidak bisa dipisahkan dari komunikasi yang dilakukan manusia. Keberadaan humor secara umum digunakan masyarakat sebagai sarana hiburan. Pada komunikasi sehari-hari pun tidak terlepas dari humor, baik untuk mencairkan suasana, candaan semata, saling sindir, dan bergurau. Semua itu dilakukan agar dapat dijadikan pelepas stress dari rutinitas sehari-hari. Pembuat atau penutur humor dalam berkomunikasi memang sengaja dalam komunikasinya di buat sedemikian rupa agar menimbulkan efek lucu dan tawa dari penerima atau lawan tutur humor. Menurut pendapat Listiyorini humor disampaikan bukan semata-mata hanya sebagai hiburan, tetapi ada kalanya juga sebagai kritik secara tersirat lewat humor tersebut (Listiyorini). Jadi kebudayaan berhumor tidak dapat dipisahkan dalam kebudayaan masyarakat yang dijadikan sebagai hiburan ataupun sarana mengkritik.
Humor disikapi sebagai wacana dapat diamati dari cara penyampaian, humor secara lisan seperti lawak, ludruk, dagelan, serta ketoprak. Selanjutnya penyampaian humor melalui tulis seperti, kartun, wayang, dan karikatur. Sebagaiamana pendapat Mubarokah, Djatmika, dan Sumarlam humor dapat diwujudkan dalam bentuk wacana, baik yang lisan maupun tulis (Mubarokah, Djatmika and Sumarlam). Dari hal tersebut diketahui bahwa humor berbentuk lisan dan berbentuk tulisan dapat dianggap wacana.

Wacana humor memiliki kemiripan karakteristik dengan anekdot. Kemiripan tersebut dapat diamati dari, (1) isi atau konten, (2) tujuan, dan (3) cara penyampaian. Keduanya bermuatan gurauan atau guyonan yang dilengkapi dengan memberikan pembelajaran kepada masyarakat melalui sindiran dan kritikan secara tidak langsung. Sebagaimana pendapat Wiradinata MP, Titin dan Zuhri. anekdot tidak hanya menyajikan hal yang lucu-lucu, guyonan atau humor, tetapi juga menyajikan tujuan lain di balik cerita lucu itu, yakni berupa pesan yang diharapkan bisa memberikan pelajaran kepada khalayak (Wiradinata MP, Titin and Zuhri). Menurut pendapat Wijana dalam Wiradinata MP, Titin dan Zuhri wacana bermuatan humor untuk bersendau gurau, menyindir, atau mengkritik secara tidak langsung segala macam kepincangan atau ketidakberesan yang tengah terjadi di masyarakat penciptanya (Wiradinata MP, Titin and Zuhri). Dari kedua pendapat tersebut dapat disimpulkan bahwa keberadaan wacana humor menjadi penting dalam sebuah interaksi karena, kemanpuan sebagai kontrol sosial, menghibur, dan sarana kritik sosial. Kajian wacana humor dapat dimanfaatkan sebagai panduan menulis anekdot karena karakteristik verbal dan tujuan tersebut.

Wacana humor memiliki prinsip, konteks, dan struktur yang dijadikan dalam rangcangan atau acuan suatu teks anekdot. Sebagaimana pendapat Mayora Syahrul dan Tressyalina unsur lucu teks anekdot adalah kata kata yang memuat humor dalam teks tersebut yang bertujuan untuk bersenda gurau, atau menyindir, mengkritik ketidakberesan yang terjadi di masyarakat 
penciptanya (Mayora, Syahrul and Tressyalina). Menurut pendapat Ermawati teks anekdot adalah teks yang di dalamnya berisi cerita lucu (Ermawati). Oleh karena itu, dapat dikatakan bahwa wacana humor merupakan komponen terpenting anekdot. Di samping itu, wacana humor memuat prinsip, konteks, dan struktur yang dijadikan sebagai rancangan atau acuan dalam menulis teks anekdot.

Keterampilan menulis termasuk dalam menulis anekdot memiliki tingkat kesulitan tertentu sebagaimana dikemukakan Gumelar dan Mulyati bahwa keterampilan menulis teks anekdot masih rendah, yang menjadi faktor utama penyebabnya ialah kesulitan dalam menuangkan pemikiran dan kreativitas (Gumelar and Mulyati). Dalam konteks lain, menurut Musyafa keterampilan menulis sulit dikuasi karena membutuhkan wawasan dan kepiawaian menyampaiakan gagasan dan ide (Musyafa). Dengan demikian, dapat disimpulkan kerampilan menulis merupakan keterampilan yang memiliki tingkat kesulitan yang tinggi dikarenakan bersifat produktif dan ekspresif sehingga dibutuhkan pengembangkan langkah-langkah pembelajaran.

Pembelajaran berbasis teks dalam pembelajaran bahasa Indonesia pada kurikulum 2013 adalah penerapan fungsi bahasa, serta mengeser paradigma bahasa sebagai alat komunikasi menjadi bahasa sebagai sebuah wacana dengan memperhatikan teks serta konteks yang menyertainya. Sebagaimana pendapat Wiradinata MP, Titin dan Zuhri pada pembelajaran bahasa berbasis teks, pemahaman dari bahasa didefinisikan sebagai alat komunikasi bahasa dipandang sebagai wacana, yaitu teks dan konteks (Wiradinata MP, Titin and Zuhri). Hal tersebut telah membawa perubahan implikasi metodologis strategi pembelajaran yang tepat atau khas. Oleh karena itu, dibutuhkan pengembangan materi yang memadai. Dengan demikian, perlu penelitian altenatif pengembangan bahan ajar. Maka dapat ditarik kesimpulan bahwa wacana berkontribusi banyak pada pembelajaran bahasa Indonesia saat ini.
Terdapat beberapa alasan mengapa acara Bajigur TV dijadikan sebagai objek penelitian. Pertama, WHBTV memuat kritikan terhadap kebiasaan kurang baik pihak tertentu. Kedua, humor yang ditampilkan dalam bentuk percakapan atau dialog yang dikolaborasikan dengan ekspresi lucu antar pemain yang terlibat, sehingga terkesan menarik dan tidak membosankan. Ketiga, WHBTV pantas dijadikan sebagai hiburan masyarakat, sebab humor yang ditampilkan tidak memuat kekerasan dan unsur SARA. Keempat, WHBTV disukai masyarakat melalui jumlah pengunjung (viewer) dan pelanggan (subscribe) yang dimiliki.

Berkaitan dengan hal itu, artikel ini akan mendeskripsikan wujud wacana yang berupa tanda-tanda lingual dan nonlingual, prinsip humor yang dapat diterima penonton dengan pempertimbangkan batas kesopanan, dan teknik humor yang dapat memberikan penjelasan secara rasioanal atas respon tawa penonton.

\section{METODE}

Penelitian dilakukan mengunakan rancangan penelitian kualitatif. Jenis penelitian yang digunakan adalah penelitian kualitatifetnografi berbahasa. Penelitian menggunakan pendekatan analisis wacana percakapan dengan menggunakan teori fitur-fitur konteks SPEAKING. Menurut pendapat Putry fiturfitur konteks SPEAKING merupakan metode analisis yang paling tepat digunakan menganalisis peristiwa tutur karena dibagi menjadi beberapa aspek, sehingga analisis menjadi lebih jelas dan detil (Putry).

Data untuk menjawab semua rumusan masalah pada penelitian adalah tuturan serta ekspresi wajah para pemain dalam Bajigur TV. Menurut pendapat Sugiarto Data yaitu bahan dalam penelitian yang nantinya diteliti (E. Sugiarto).

Sumber data penelitian adalah video cerita lucu unggahan kanal Bajigur TV. Menurut pendapat Arikunto sumber data dalam penelitian ini adalah subjek dari mana data dapat diperoleh (Arikunto). 
Teknik pengumpulan data yang digunakan dalam penelitian menggunakan teknik dokumentasi dan teknik transkripsi. Tahapan teknik dokomentasi pada penelitian terdiri atas, mengunduh, mencermati, dan mengklasifikasikan wacana humor yang termuat dalam video pada kanal tersebut dalam kategori rumusan masalah. Teknik transkripsi dilakukan dengan cara mentraskrip dan menyajikan data dalam bentuk tulisan.

Menurut pendapat Sugiyono analisis data adalah proses mencari dan menyusun data secara sistematis (Sugiyono). Teknik analisis data pada penelitian yaitu reduksi data, penyajian data, dan penarikan kesimpulan. Terdapat dua instrumen penelitian yang digunakan dalam penelitian, yaitu instrumen utama peneliti sendiri, dan instrument tambahan meliputi instrument pengumpul data, instrumen analisis data.

Prosedur penelitian meliputi tiga tahap, yaitu: (1) tahap persiapan, (2) tahap pelaksanaan, dan (3) tahap penyelesaian.

\section{HASIL PENELITIAN}

Pada bagian ini diuraikan hasil dan pembahasan tentang WHBTV dan pemanfaatannya sebagai bahan ajar menulis anekdot di SMA kelas X. Sesuai dengan masalah dan tujuan penelitian, pembahasan terdiri atas empat hal antara lain: (1) wujud WHBTV; (2) prinsip humor dalam WHBTV; (3) teknik humor WHBTV; dan (4) pemanfaatan WHB TV untuk materi ajar menulis teks anekdot di SMA Kelas X. Pembahasan lebih lanjut akan diuraikan sebagai berikut.

\section{Wujud dalam Wacana}

Wujud wacana humor yang menyertai setiap tayangan video lucu yang diunggah Bajigur TV pada Youtube memiliki keunikan dan keberagaman dalam setiap unggahan. Wujud wacana humor merupakan bentuk penyampaian berupa tanda lingual dan nonlingual sebagai penjelasan situasi yang selalu ada dalam setiap wujud wacana humor yang ditemukan. Temuan wujud wacana humor yang dalam penelitian ini berdasarkan komponen atau isi wacana, bentuk wacana, dan susunan wacana yang terdapat pada WHBT. Wujud tersebut antara lain: (1) ejekan terhadap pekerjaan, (2) penyebab emosi, (3) memanfaatkan kesusahan, (4) tawaran mengecewakan, (5) tipuan, (6) menggoda wanita, (7) melebih-lebihkan hal sepele, (8) memberikan alasan berubah-ubah, (9) menjelaskan hal unik tidak masuk akal, (10) olokan tertentu, dan (11) dugaan salah.

\section{Ejekan terhadap Pekerjaan Seseorang}

Wujud WHBTV berupa ejekan terhadap pekerjaan seseorang diindikasikan dengan ejekan terhadap perkerjaan seseorang (merendahkan pekerjaan tersebut). Wujud tersebut dipaparkan sebagai berikut

Kunci Motor Hilang (video unggahan 14 Juli 2019)

(...)

Pemain 2 : "Eh Mo Lo tahu enggak? Si Qinoy punya mobil baru."

Pemain 1 : "Lah emang terus kenapa?"

Pemain 2 : "Yah kan Qinoy kerjaannya apaan sih? kerjaannya cuma dudukduduk doang masak punya mobil baru." Pemain 1 : "Yah kan Dia supir angkot, ya kerjaannya duduk, masak Dia berdiri ?"

(...)

Konteks : pemain 1 dan pemain 2 saling berdialog yang awalnya membahas tentang pekerjaan seseorang yang membuat pemain 2 iri. Kemudian ditutup dengan penjelasan pemain 1 yang menimbulkan gelak tawa pekerjaan sebenarnya orang yang maksud.

Wujud wacana tersebut adalah ejekan terhadap pekerjaan seseorang. Kalimat pernyataan pemain 2 bermakna merendahkan seseorang yang dibahas. Pemain 2 merasa iri dengan yang dicapainya, kemudian diingatkan oleh pemain 1 . 


\section{Penyebab Emosi}

Ujaran WHBTV berupa penyebab emosi dapat diindikasikan dengan percakapan penyebab emosi atau rasa kesal terhadap lawan bicara dalam hal ini pemain lain. Wujud tersebut dipaparkan sebagai berikut.

\section{Rokok di Surga (video unggahan 22 Januari 2019) \\ (...)}

Pemain 2 : "Saya ini suka rokok. Tapi apa di surga boleh ngerokok Pak RT ?"

Pemain 1 : "Di surga ya? Kalau menurut Saya sih boleh-boleh aja."

Pemain 2 : "Oh gitu Pak RT ?"

Pemain 1: "Ya ini setahu Saya aja loh ya. Itu soalnya kalau sudah di surga itu, Kita boleh melakukan apa aja.

Pemain 2: "Wah boleh juga tuh Pak RT."

Pemain 1 : "Ya.. tapi ya ada tapinya loh."

Pemain 2: "Kok ada tapinya Pak RT ?"

Pemain 1: "Ya, menurut Saya di surga itu enggak ada api. Jadi kalau Sampean mau ngerokok ya lari ke neraka dulu."

Pemain 2 : (menunjukkan ekspresi kecewa dengan menyandarkan kepala di kursi).

Konteks : pemain 1 dan pemain 2 saling berdialog yang awalnya membahas tentang merokok di surga. Kemudian ditutup dengan penjelasan pemain 1 yang menimbulkan gelak tawa yaitu di surga tidak ada api jadi harus ke neraka terlebih dahulu.

Wujud wacana tersebut adalah nasihat yang menimbulkan emosi Pak RT (P1) kepada Bemo (P2). Apabila dilihat dari kalimat yang membangun, wujud tersebut merupakan kalimat yang menyebabkan emosi (geram atau marah). Pernyataan, "Ya, menurut Saya di surga itu enggak ada api. Jadi, kalau Sampean mau ngerokok ya lari ke neraka dulu"
Kalimat tersebut membuat lawan tutur tidak nyaman. Respons emosional yang ditunjukkan pemain 2 dengan menunjukkan ekspresi kecewa dengan menyandarkan kepala di kursi.

\section{Memanfaatkan Kesusahan}

Wujud WHBTV berupa memanfaatkan kesusahan orang lain diindikasiakan dengan pernyataan yang memanfaatkan kesusahan lawan bicara dalam hal ini pemain lain. Wujud tersebut dipaparkan sebagai berikut.

Kesasar (video unggahan 30 Januari 2019)

Pemain 1 : "Permisi Mas numpang tanya. Kalau pasar buaya gang oleng tahu enggak?"

Pemain 2 : "Wah enggak tahu Saya Mas.

Pemain 1 : "Kalau jalan utama tahu? Mas emang mau ke mana?"

Pemain 2 : "Justru itu, Saya udah nyasar di sini tiga hari. Selamat Saya, untung ada Abang."

Konteks : pemain 1 dan pemain 2 saling berdialog yang awalnya membahas tentang alamat jalan tertentu. Kemudian ditutup dengan penjelasan pemain 2 yang menimbulkan gelak tawa yang ternyata sama-sama tersesat di sana.

Kalimat yang membangun wujud data tersebut, menggunakan kalimat yang menjelaskan bahwa pemain 2 sedang menanfaatkan kondisi pemain 1. Sebagaimana cuplikan kalimat berikut. "Justru itu Saya udah nyasar di sini tiga hari. Selamat Saya untung ada Abang." Pemain 2 menunjukkan sikap memanfaatkan kondisi pemain 1 yang sedang tersesat sebab pemain 1 sudah lebih dahulu tersesat di lokasi tersebut.

\section{Tawaran Mengecewakan}

Wujud WHBTV berupa tawaran yang mengecewakan terdapat pada data dengan diindikasikan dengan tawaran yang menge- 
104 Alinea: Jurnal Bahasa, Sastra, dan Pengajaran Volume 9, (2) Oktober 2020, hal. 99-117

cewakan terhadap lawan bicara dalam hal ini pemain lain. Wujud tersebut dipaparkan sebagai berikut.

Kredit HP (video unggahan 13 Februari 2019)

(...)

Pemain 2 : "Kayaknya kalau sekarang

Gue enggak bisa tapi kalau mau Gue cicil mau enggak ?"

Pemain 1 : "Duh cicil ya, Gue butuh sekarang sih tapi ya udah lah enggak papa lah."

Pemain 2 : "Gini aja Gue cicil, tiap

bulan Gue kasih goceng. Selama 60 kali."

Pemain 1 : "Jadi nih HP Gue lunas selama 5 tahun?"

Pemain 2 : "Ya begitu."

Pemain 1 : "Ah gila Lo Ndro."

Konteks : pemain 1 dan pemain 2 saling berdialog yang awalnya membahas tentang harga telepon genggam. Kemudian ditutup dengan penjelasan pemain 2 yang menimbulkan gelak tawa yang ternyata mengangsur telepon genggam tersebut.

Kalimat tersebut menunjukkan pernyataan yang mengecewakan lawan bicara. Sebagaimana cuplikan kalimat berikut, "Gini aja Gue cicil tiap bulan Gue kasih goceng selama 60 kali." Kalimat tersebut dituturkan pemain 2 yang ingin membeli telepon genggam pemain 1 dengan harga 300 ribu, namun menawar dengan mengangsurnya sebanyak lima ribu atau lebih sering disebut dengan istilah goceng setiap bulannya. Tanggapan pemain 1 diucapkankan dengan ungkapan "Ah gila Lo Ndro", ungkapan tersebut memiliki maksud untuk mempertegas bahwa tawaran pemain 2 untuk membeli telepon gengang seharga 300 ribu dengan cara mengangsurnya dengan lima ribu rupiah setiap bulan adalah suatu hal yang tidak masuk akal serta menimbulkan kekecewaan.

\section{Tipuan}

Wujud WHBTV diindikasikan dengan pernyataan yang menipu lawan bicara dalam hal ini pemain lain. Wujud tersebut dipaparkan sebagai berikut.

Ojek Baru (video unggahan 30 Januari 2019)

(...)

Pemain 1: "Hmm, kalau dari sini ke blok M berapa Mas?"

Pemain 2 : "Ke blok M 30 ribu, yuk."

Pemain 1 : "Kalau ke monas?"

Pemain 2 : “Kalau ke monas gocap dah yuk, udah siap.

Pemain 1 : "Kalau belok ke ragunan?"

Pemain 2 : "Ragunan. 100 ribu dah. Sebenernya Mas mau ke mana sih ?"

Pemain 1 : "Sebenernya Saya cuma tanya harganya sih Mas. Saya juga ojek baru di sini. Mbak-Mbak, Mas-Mas ojek-ojek ke blok M 25 ribu. Kalau sama yang belakang mah mahal 30 ribu. Ayo Dek-Dek ojek Dek."

Konteks : pemain 1 dan pemain 2 saling berdialog yang awalnya membahas tentang harga naik ojek. Kemudian ditutup dengan penjelasan pemain 1 yang menimbulkan gelak tawa yang ternyata tukang ojek baru.

Kalimat pemain 1, "Saya juga ojek baru di sini. Mbak-Mbak, Mas-Mas ojek-ojek ke blok M 25 ribu. Kalau sama yang belakang mah mahal 30 ribu." memiliki tujuan untuk menipu lawan bicara. Tuturan pemain 2 yang dijadikan alasan menanyakan harga naik ojek menuju beberapa tempat, bertujuan utama pemain 2 menuturkan kalimat tersebut untuk mengelabui pemain 1 sebab dia sendiri juga tukang ojek baru di kawasan tersebut.

\section{Menggoda Wanita}

Wujud WHBTV berupa pernyataan yang menggoda wanita terdapat pernyataan yang merayu seorang wanita dalam hal ini lawan 
bicara atau pemain lain. Wujud tersebut dipaparkan sebagai berikut.

(Data 18) Gombal Gembel (video unggahan 26 Maret 2019)

(...)

Pemain 1 : "Ini Aku lagi liatin Kamu.

Sar, Kaтu mau tahu enggak kayaknya

kalau Aku disuruh melupakanmu Aku bakal pergi ke kelurahan dulu deh."

Pemain 2 : "Loh emangnya kenapa?"

Pemain 1: "Iya Aku mau minta surat keterangan tidak mampu untuk melupakanmu."

Pemain 2 : (Tersipu malu menanggapinya sampai tidak segaja memakan bunga matahari).

Konteks : pemain 1 dan pemain 2 saling berdialog yang awalnya membahas tentang hal yang sedang dilakukan. Kemudian ditutup dengan penjelasan pemain 1 yang menimbulkan gelak tawa yang menggoda pemain 2 .

Memalui analisis fitur-fitur kontek ditemukan wujud wacana yaitu menggoda wanita oleh Qinoy (P1) kepada Sarah (P2). Apabila dilihat dari kalimat yang membangun wujud tersebut menggunakan kalimat yang memuat rayuan. Sebagaimana cuplikan kalimat berikut. "Iya Aku mau minta surat keterangan tidak mampu untuk melupakanmu." membuat lawan tuturannya merasa terpesona mendengarnya. Sarah (P2) dengan malu-malu menanggapinya sambil menatap mata Qinoy (P1) dengan tidak sadar memetik bunga matahari dan memakannya lalu meludahkannya sebab pahit. Berdasarkan analisis tersebut dapat disimpulkan bahwa data dengan kode $\mathrm{GW} / \mathrm{ID}_{1}$ tersebut memiliki wujud berupa menggoda wanita

\section{Melebih-lebihkan Hal Sepele}

Wujud WHBTV berupa pertanyaan melebih-lebihkan hal sepele terdapat pada data dengan kode $\mathrm{LH} / \mathrm{LO}_{1}$ yang mengindikasikan penjelasan suatu hal secara berlebihan yang menimbulkan rasa kesal terhadap lawan bicara dalam hal ini pemain lain. Wujud tersebut dipaparkan sebagai berikut.

Menu Favorit (video unggahan 22 Juli 2019)

Pemain 1 : "Permisi Mas ada yang bisa Saya bantu?"

Pemain 2 : "Di sini itu menu favoritnya itu apa Mas?"

Pemain 1 : "Banyak Mas di sini ada banana soup with cassava and Javanese sugar."

Pemain 2 : "Wah apa itu Mas ?"

Pemain 1 : "Oh itu kolak pisang Mas."

Pemain 2 : "Kolak pisang toh, terus apa lagi?"

Pemain 1 : "Sticky rice filled abon with chiken and banana leaf."

Pemain 2 : "Kayaknya enak tuh, apa itu Mas?"

Pemain 1 : "Lemper Mas."

(...)

Konteks : pemain 1 dan pemain 2 saling berdialog yang awalnya membahas tentang menu favorit di restoran tersebut dengan menggunakan istilah asing, sehingga membuat pemain 1 sebagai pengunjung restoran kebinggungan. Penggunaan istilah asing tersebut menjadi hal unik tersendiri dan terkesan lucu.

Memalui analisis fitur-fitur kontek ditemukan wujud wacana tersebut adalah melebih-lebihkan hal sepele oleh Bemo yang berperan sebagai pelayan (P1) kepada Qinoy yang berperan sebagai pembeli (P2). Kalimat "Sticky rice filled abon with chiken and banana leaf " "Kayaknya enak tuh, apa itu Mas?" "Lemper Mas. " membuat lawan tuturannya merasa kesal. Pemain 2 dengan tenang menanggapinya dengan tersenyum. Berdasarkan analisis tersebut dapat disimpulkan bahwa data tersebut memiliki wujud melebih-lebihkan hal sepele. 
106 Alinea: Jurnal Bahasa, Sastra, dan Pengajaran Volume 9, (2) Oktober 2020, hal. 99-117

\section{Memberikan Alasan Berubah-ubah}

Wujud WHBTV berupa memberikan alasan berubah-ubah terdapat pada data dengan kode $\mathrm{AB} / \mathrm{KB} / \mathrm{ID}_{1}$ yang mengindikasikan pernyataan yang menyampaikan alasan tertentu kepada lawan bicara dalam hal ini pemain lain. Wujud tersebut dipaparkan sebagai berikut.

Pergi ke Masjid (video unggahan $7 \mathrm{Mei}$ 2019)

(...)

Pemain 2 : "Gue mau sholat berjamaah lah ke masjid biar banyak pahalanya."

Pemain 1 : "Alah Lo paling mau nyolong sandal. Iya kan?"

Pemain 2 : "Edah kalau ngomong enggak pakek diayak dulu itu kata-kata, inget ini bulan puasa loh Sar."

Pemain 1 : "Sorry Noy lah terus, itu tuh sendal kenapa lo tenteng-tenteng? Kayak gembel lo."

Pemain 2 : "Iya ini Gue mau nuker sendal, soalnya yang Gue ambil kemarin kekecilan."

Pemain 1 : "Aduh dasar keset masjid."

Konteks : pemain 1 dan pemain 2 saling berdialog yang awalnya membahas tentang alasan pemain 2 pergi ke masjid. Kemudian ditutup dengan penjelasan pemain 2 yang menimbulkan gelak tawa yang ternyata alasan pemain 2 pergi ke masjid mau menukarkan sandal hasil mencuri kemarin yang kekecilan.

Dilihat dari konteks kalimat yang membangun, wujud tersebut menggunakan kalimat yang berisi penyampaian alasan tertentu. Sebagaimana cuplikan kalimat berikut. "Sorry Noy lah terus, itu tuh sendal kenapa Lo tenteng-tenteng? Kayak gembel Lo" "Iya ini Gue mau nuker sendal, soalnya yang Gue ambil kemarin kekecilan." Kalimat tersebut memuat alasan pergi ke masjid untuk menukar sandal karena kekecilan. Alasan tersebut digunakan Qinoy (P2) untuk menghindari tuduhan mencuri sandal yang diucapkan Sarah (P1). Sarah (P1) menanggapinya dengan mengejek dengan sebutan aneh kepeda Qinoy (P2).

\section{Menjelaskan Hal Unik tidak Masuk Akal}

Wujud WHBTV berupa menjelaskan hal unik tidak masuk akal terdapat pada pernyataan yang berisikan hal unik oleh lawan bicara dalam hal ini pemain lain. Wujud tersebut dipaparkan sebagai berikut.

Cara Berhenti Rokok (video unggahan 22 Januari 2019)

(...)

Pemain 1 : "Gini Pak Ustadz, Saya ini kan seneng ngerokok. Gimana ya caranya supaya Saya bisa berhenti merokok? Kayaknya nih mulut asem terus."

Pemain 2 : "Gampang caranya, Kamu bakar depan belakangnya tuh rokok. Saya jamin pasti Kamu berhenti."

Pemain 1 : "Wah, Saya jadi gak bisa ngerokok kalau gitu?"

Pemain 2 : "Loh iya bagus itu."

Pemain 1 : "Kalau gitu rokok Saya buat Pak Ustadz aja deh."

Pemain 2 : Alhamdulillah dapet rokok, makasih ya."

Konteks : pemain 1 dan pemain 2 saling berdialog yang awalnya membahas tentang cara berhenti merokok. Kemudian ditutup dengan penjelasan pemain 2 yang menimbulkan gelak tawa yang menyuruh orang berhenti rokok tapi dia nya sendiri perokok.

Wujud wacana tersebut adalah penjelasan hal unik tidak masuk akal oleh Bemo sebagai Pak Ustadz (P2). Kalimat yang membangun wujud tersebut menyampaikan hal unik dalam kalimat, "Gampang caranya, Kamu bakar depan belakangnya tuh rokok. Saya jamin pasti Kamu berhenti.", hal unik yang disampaikan melalui kalimat tersebut ialah cara berhenti merokok dengan membakar kedua ujung rokok, sehingga tidak bisa lagi merokok. Pemain 1 dengan pasrah menang- 
gapinya sambil memberikan rokok tersebut kepada pemain 2 (Pak Ustadz)

\section{Olokan Tertentu}

Wujud WHBTV berupa olokan tertentu terdapat pada data yang mengindikasikan olokan tertentu terhadap lawan bicara dalam hal ini pemain lain. Wujud tersebut dipaparkan sebagai berikut.

Pergi ke Masjid (video unggahan 7 Mei 2019)

Pemain 2 : "Gue mau sholat berjamaah lah ke masjid biar banyak pahalanya."

Pemain 1 : "Alah Lo paling mau nyolong sandal. Iya kan?"

Pemain 2 : "Edah kalau ngomong enggak pakek diayak dulu itu kata-kata, inget ini bulan puasa loh Sar."

Pemain 1: "Sorry Noy lah terus, itu tuh sendal kenapa Lo tenteng-tenteng? Kayak gembel Lo."

Pemain 2 : "Iya ini Gue mau nuker sendal, soalnya yang Gue ambil kemarin kekecilan."

Pemain 1 : "Aduh dasar keset masjid."

Konteks : pemain 1 dan pemain 2 saling berdialog yang awalnya membahas tentang alasan pemain 2 pergi ke masjid. Kemudian ditutup dengan penjelasan pemain 2 yang menimbulkan gelak tawa yang ternyata alasan pemain 2 pergi ke masjid ingin menukarkan sandal hasil mencuri kemarin yang kekecilan.

Berdasarkan analisis konteks dapat diketahui bahwa wujud wacana tersebut adalah berupa olokan tertentu oleh Sarah (P1) kepada Qinoy (P2). Apabila dilihat dari kalimat yang membangun wujud tersebut menggunakan kalimat yang langsung menyebut nama seseorang dengan nama barang tertentu atau dengan perbandingan objek lain. Terdapat pada tuturan Pemain 1 (P1) : Aduh dasar keset masjid membuat lawan tuturannya merasa kesal. Sarah (P1) dengan kecewa menanggapinya dengan mengejek dengan sebutan aneh kepeda Qinoy (P2).

\section{Dugaan Salah}

Wujud WHBTV berupa dugaan salah terdapat pada data yang mengindikasikan dugaan salah terhadap hal yang dimaksud lawan bicara dalam hal ini pemain lain. Wujud tersebut dipaparkan sebagai berikut.

Kerjaan Baru (video unggahan 12 Maret 2019)

Pemain 1 : "Hey Mo! Lo siang-siang gini ada di sini, Lo enggak berangkat kerja?"

Pemain 2 : "Tahu dah nih Pi, Gue habis kontrak."

Pemain 1 : "Habis kontrak ? Emang kontrakan, Lo makan?'

Pemain 2: "Maksud Gue, Gue udah enggak kerja lagi. Kontrak Gue udah habis."

(...)

Konteks : pemain 1 dan pemain 2 saling berdialog yang awalnya membahas tentang lowongan pekerjaan. Kemudian di saat percakapan berlangsung terjadi salah dugaan oleh pemain 1 dengan apa yang dimaksud pemain 2 .

Berdasarkan analisis konteks dapat diketahui bahwa tuturan tersebut merupakan dugaan salah Yupi (P1) terhadap Bemo (P2). Kalimat yang membangun wujud tersebut menggunakan kalimat yang salah memahami kata tertentu, "Abis kontrak? Emang kontrakan, Lo makan?" "Maksud gue, gue udah enggak kerja lagi. Kontrak Gue udah habis." Pada percakapan tersebut terdapat kesalahpahaman pemain 1 mengartikan hal yang dimaksud pemain 2, yaitu habis kontrak kerja dengan menghabiskan kontrakan

\section{Prinsip Humor}

Prinsip humor dalam WHBTV merupakan perwujudan dari ucapan dalam percakapan antara pemain yang mampu menciptakan kelucuan. Pemain yang ikut serta tidak dapat sepenuhnya memakai prinsip humor karena harus memperhitungkan apa yang menjadi 
tujuan tuturan, mitra tutur, konteks tuturan. Prinsip humor dapat dianalisis melalui kesepakatan berhumor, penggunaan tuturan yang berlebihan, penyampaian kritikan, menggunakan kata-kata brutal dalam batas kesopanan guna memancing senyum dan tawa penonton dapat dipaparkan sebagai berikut.

\section{Prinsip Kesepakatan Berhumor}

Kesepakatan berhumor mengharuskan adanya kesepakatan antara pihak-pihak yang akan menyampaikan humor. Kesepakatan tersebut yaitu kesepakatan menyadari antara kebenaran dan ketidakkebenaran yang termuat dalam humor sebaga bahan candaan semata. Prinsip kesepakatan berhumor akan dipaparkan sebagai berikut.

Wacana humor tersebut yang menceritakan pemain 1 (Qinoy) (data wujud humor nomor 5) terus menerus menanyakan harga naik ojek ke beberapa tempat tujuan seperti, ke Monas, Ragunan, dan Blok M. Wacana humor tersebut tergolong ke dalam prinsip kesepakatan berhumor karena penggunaan prinsip tersebut mengharuskan menggunakan kesepakatan antara pemain yang terlibat yang akan menyampaikan humor lewat dialog atau percakapan, yaitu batas antara kebenaran dan ketidakbenaran atau rekaan dalam humor yang dituturkan telah tidak ada lagi. Sehingga semua isi percakapan anatara pemain 1 dan pemain 2 yang terlibat hanyalah sebatas humor, kelakar atau guyonan.

\section{Menggunakan Tuturan yang Berlebihan (Hiperbola)}

Tuturan yang berlebihan ialah peserta tutur menyampaikan sumbangsih berlebihan dari yang diperlukan oleh lawan bicaranya. Mitra tutur mendapatkan informasi yang melebihi kebutuhannya. Bagian-bagian yang berisi informasi yang tidak diperlukan oleh mitra tutur tetap dituturkan untuk menghibur penonton, sehingga membuat humor menjadi lucu dan menarik. Wacana humor tersebut berisi tuturan percakapan antara pemain $1 \mathrm{Pak}$ RT dengan pemain 2 Bemo yang membicarakan tentang nasib seorang yang memiliki hobi merokok jika sudah di surga nantinya (data wujud humor nomor 2). Pemain 2 menjelaskan bahwa dia merupakan orang yang suka merokok. Dia juga menanyakan apakah di surga nanti boleh merokok. Pemain 1 Pak RT menjelaskan bahwa di surga nanti boleh merokok, karena orang yang masuk surga itu boleh meminta saja apa saja yang diinginkan.

Wacana humor tersebut termasuk ke dalam prinsip humor menggunakan tuturan berlebihan, karena pemain 1 Pak RT memberikan informasi yang berlebihan dari yang dibutuhkan pemain 2 Bemo yaitu kalimat " $Y a$, menurut Saya di surga itu enggak ada api. Jadi kalau Sampean mau ngerokok ya lari ke neraka dulu". Pemain 1 Pak RT menambahkan tuturan bahwa di surga itu tidak ada api, sehingga harus masuk neraka dulu karena di sana terdapat banyak api. Pernyataan pemain 1 Pak RT tersebut berisi humor tersendiri sekaligus membuat pemain 1 Bemo merasa kecewa, ekspresi kekecewaan tersebut ditunjukkan dengan menyandarkan kepalanya di kursi.

Penggunaan tuturan yang berlebihan oleh pemain 1 Pak RT tidak serta merta digunakan karena juga harus memperhatikan lawan bicara, tujuan tuturan, dan konteks tuturan. Pemain 1 Pak RT dapat menggunakan tuturan berlebihan tersebut karena dalam situasi berhumor, sehingga penonton pun tidak masalah dengan tuturan tersebut.

Prinsip menggunakan tuturan yang berlebihan juga terdapat pada wacana humor percakapan antara pemain 1 (Yupi) dan pemain 2 (Pak Ustadz) (data wujud tuturan nomor 9) Wacana humor tersebut masuk ke dalam prinsip humor tuturan berlebihan karena memberikan informasi berlebihan dan bukan info yang diperlukan oleh pemain 1. Pemain 2 Pak Ustadz mengatakan "Kamu bakar depan belakangnya tuh rokok. Saya jamin pasti Kamu berhenti" . Dalam kehidupan seharihari, hal tersebut tidak mungkin dilakukan oleh orang yang ingin berhenti merokok. 
Tuturan tersebut tidak ternasuk kedalam informasi yang ingin diperoleh oleh mitra tutur atau pemain 1 .

\section{Penyampaian Kritikan dengan Ironi, Sinisme, dan Sarkasme}

Humor yang berupa kritikan dapat dijumpai menggunakan gaya ironi, sisnisme, dan sarkasme. Penyampaian kritikan tersebut akan dipaparkan sebagai berikut.

\section{a. Kritikan dengan Ironi}

Obat Awet Muda (video unggahan 18 Juni 2019)

Pemain 1 : "Huu mandi, mandi, mandi." Pemain 2 : "Widih rajin bener nih pagipagi mandiin taneman yang nyiram udah mandi apa blum nih."

Pemain 1 : "Pakek ditanya lagi udah jelas lah belum mandi."

Pemain 2 : "Mo kalau Gue liat-liat sekarang muka Lo kusut Mo agak keriput lagi tuh."

Pemain 1 : "Masak iya sih kriput emang agak tua apah."

(...)

Konteks: Pemain 1 dan pemain 2 saling berdialog yang awalnya membahas tentang hal yang sedang dilakukan pemain 1. Kemudian berlanjut dengan membahas kekeriputan yang dialami pemain 2 .

Wacana humor tersebut berisi percakapan antara pemain 1 (Bemo) dan pemain 2 (Qinoy) yang membicarakan tentang kekeriputan yang dialami oleh pemain 1 . Wacana humor tersebut termasuk ke dalam prinsip humor kritikan dengan ironi karena mengkritik kebiasaan buruk malas mandi di pagi hari. Pernytaan pemain 2, "Widih rajin bener nih pagi-pagi mandiin taneman yang nyiram udah mandi apa blum nih" tersebut menggunakan gaya ironi yaitu memberikan kesan tidak sopan melalui sikapnya yang "seakan-akan sopan" dengan mengatakan rajin memandikan tanaman di pagi hari, sekaligus menghujat melalui pertanyaan apakah pemain 1 Bemo yang menyiram tanaman tersebut sudah mandi. Penggunaan kritikan dengan gaya ironi dalam wacana humor tersebut harus disertai dengan kesepakatan untuk mendapat respon pernyataan yang mendukung kelucuan. Dalam data tersebut pemain 1 yang dengan mudah membenarkan bahwa dirinya memang belum mandi. Wacana humor kritikan dengan ironi tersebut mendapat respon baik oleh lawan bicara (pemain 1).

\section{b. Kritikan dengan Sinisme}

Sinisme ialah gaya celaan atau ejekan menggunakan hal-hal yang bertentangan agar orang yang dikritik merasa tersindir secara lebih mengena pada dirinya.

Motor Hitam (video unggahan 18 Juni 2019)

(...)

Pemain 1 : "Ngomong-ngomong motor di rumah ada berapa?"

Pemain 2 : "Yah ini doang satu-satunya ini juga belum lunas masih kredit."

Pemain 1 : "Ini motor sering Lo jemur ya?"

Pemain 2 : "Ya namanya kan ojek kena panas-panas lah."

Pemain 1 : "Oh sering Lo jemur? Patesan item kek Lo."

Pemain 2 : "Emang ini warnanya item dasar garpu somay."

Konteks Pemain 1 dan pemain 2 saling berdialog yang awalnya membahas tentang hal yang sedang dilakukan pemain 2 yaitu bersih-bersih motor. Kemudian ditutup dengan penjelasan pemain 1 yang menimbulkan gelak tawa yang menyamakan warna kulit dengan motor yang sering dijemur.

Wacana humor tersebut berisi percakapan antara pemain 1 (Yupi) dan pemain 2 (Bemo) yang menceritakan tentang kondisi sepeda motor yang dimiliki pemain 2 . Pembahasan kondisi sepeda motor milik pemain 2 lewat pernyataan pemain 1 yang 
mengatakan "Oh sering Lo jemur? Patesan item kek Lo". Kalimat tersebut berisi kritikan terhadap pemain 2 bahwa dia tidak cocok memiliki sepeda motor dengan warna hitam karena sama dengan warna kulitnya. Kalimat tersebut termasuk kritikan dengan sinisme, karena menyatakan memang warna sepeda montornya hitam bukan disebabkan kepanasan dan menjadi hitam seperti warna kulitnya. Penggunaan kritikan dengan sinisme yang dilakukan oleh pemain 1 mendapat respon baik dari pemain 2 yang tidak marah dengan humor tersebut sehingga penggunaan humor kritikan dengan sinisme yang memperhatikan tujuan tuturan menjadi tepat penggunaannya.

\section{c. Kritikan dengan Sarkasme}

Sarkasme ialah gaya celaan atau ejekan dengan memakai kata-kata pedas yang menusuk perasaan untuk melukai hati orang yang dikritik. Sarkasme yang ditemukan sebagai berikut.

Ngaji yang Benar (video unggahan 12 Mei 2019)

Pemain 1 : "Bismillahirrohmanirohim, $a k$, bak, tak, jak."

Pemain 2 : "Mo kamu gimana sih udah setahun baca iqro' aja masih salahsalah terus."

Pemain 1 : "Abisnya susah banget Ustad.

Pemain 2 : "Tuh contoh si Qinoy udah mau hatam iqro' enam dia."

Pemain 1: "Hemm, terus harus bilang waw gitu.

Pemain 2 : "Enggak usah jauh-jauh dulu, alif, ba, ta, tsa aja dulu kalau udah lancar nanti juga sampek ke wawu."

Konteks Pemain 1 dan pemain 2 saling berdialog yang awalnya membahas tentang sulitnya mengaji. Kemudian ditutup dengan penjelasan pemain 2 yang menimbulkan gelak tawa yang sedang mengingatkan pemain 1 .

Wacana humor (20) berisi percakapan antara pemain 1 (Qinoy) dan pemain 2 (Pak
Ustadz) yang menceritakan kemanpuan pemain 1 yang tidak lancar membaca huruf hijaiah. Wacana humor tersebut tergolong prinsip humor kritikan dengan sarkasme, karena mengandung teguran langsung oleh pemain 2 Pak Ustad dengan mengatakan "Enggak usah jauh-jauh dulu, alif, ba, ta, tsa aja dulu kalau udah lancar nanti juga sampek ke wawu". Kalimat tersebut merupakan katakata kasar yang langsung menusuk pemain 1 .

\section{Menggunakan Kata-kata Brutal dalam Batas Kesopanan, Guna Memancing Senyum dan Tawa Penonton}

Pada wacana humor Bajigur TV, kerap ditemukan pemain yang menggunakan katakata brutal yang masih dalam batas kesopanan dalam sebuah percakapan dengan pemain lain. Hal tersebut termasuk salah satu upaya menciptakan kelucuan dan efektif untuk meningkatkan efek humor karena kata-kata brutal lebih tepat untuk memunculkan humor terhadap penjawab (penonton).

Prinsip humor menggunakan kata-kata brutal dalam batas kesopanan dapat dicermati pada data wujud tuturan nomor 8 . Wacana humor tersebut menceritakan tentang alasan pemain 2 (Qinoy) untuk pergi ke Masjid. Pemain 1 secara terang-terangan menuduh pemain 2 mencuri sandal di masjid. Wacana humor tersebut tergolong dalam prinsip menggunakan kata-kata brutal dalam batas kesopanan. Tujuannya memancing senyum dan tawa penonton karena pemain 1 langsung menuduh pemain 2 . Pernyataan pemain 1 Sarah tersebut termasuk ke dalam konotasi buruk karena mencuri merupakan hal yang dilarang agama terlebih lagi di tempat ibadah meskipun pada akhirnya pemain 2 mengakuinya sehingga membuat penonton tertawa mendengar hal tersebut.

\section{Teknik Humor}

Teknik humor dalam WHBTV merupakan hal yang dapat memberikan penjelasan terhadap respon tawa penonton saat melihat tayangan dalam Bajigur TV pada YouTube. 
Teknik humor yang ditemukan dalam penelitian seperti (1) bahasa (language), (2) logika (logic), dan (3) identitas (identity) yang berdasarkan teori teknik humor Arthur Asa Berger. Temuan teknik humor tersebut diuraikan di bawah ini.

\section{Teknik Humor Bahasa (Language)}

Teknik humor bahasa (language) dalam Bajigur TV dilakukan dengan kata-kata, cara berbicara, makna kata, atau akibat dari katakata yang dituturkan oleh pemain-pemain yang terlibat. Beberapa teknik humor bahasa (language) tidak digunakan dalam Bajigur TV hanya beberapa saja yang digunakan. Teknik humor bahasa (language) yang digunakan seperti, omong besar (bombast), pernyataan yang dilebih-lebihkan (exaggeration), penghinaan (insults), serta ejekan (irony). Temuan teknik humor language tersebut diuraikan sebagai berikut.

\section{a. Bombastis (Bombast)}

Teknik humor bahasa (language) dengan bombastis (bombast) dalam wacana humor Bajigur TV dilakukan dengan cara mempermasalahkan suatu hal tertentu secara berlebihan dan dipaksa masuk akal. Hal tersebut didukung dengan teori teknik humor Berger dalam Sugiarto yang menyatakan bahwa teknik humor bahasa (language) dengan bentuk bombastis (bombast) yaitu teknik dengan mencoba berbicara sesuatu yang dipaksa masuk akal dengan bicara berlebihan atau muluk-muluk (V. D. Sugiarto).

Teknik humor (pada data wujud humor nomor 1) sebagaimana di atas dengan menggunakan ucapan yang berlebih dan berusaha terdengar masuk akal. Pada segmen tutur pemain 2 berusaha merasionalkan tentang perkerjaan seseorang yang hanya dudukduduk saja, namun bisa membeli mobil. Pemain 1 menanggapi dengan uangkapan yang masuk akal tentang pekerjaan seseorang tersebut yang untuk menguatkan teknik humor. Seharusnya segmen tutur pemain 2 di atas, yang berisi kalimat tanya, membutuhkan jawaban pasti atas pertanyaan tersebut. Namun, pada segmen tutur tersebut mendapat jawaban di luar inti pertanyaan.

\section{b. Pernyataan yang Dilebih-lebihkan (Exaggeration)}

Teknik humor bahasa (language) dengan pernyataan yang dilebih-lebihkan (exaggeration) dalam wacana humor Bajigur $T V$ dilakukan dengan cara melebih-lebihkann suatu permasalahan. Salah satu pemain berusaha mengklarifikasi suatu permasalahan, tetapi terlihat lucu dan bisa diimajinasikan sebab klarifikasi tersebut tidak masuk akal. Hal tersebut didukung dengan teori teknik humor Berger dalam Sugiarto yang menyatakan bahwa teknik humor bahasa (language) dengan bentuk pernyataan yang dilebih-lebihkan (exaggeration) yaitu teknik dengan melebih-lebihkan sesuatu yang dapat menjadi lucu dan hal tersebut dapat kita imajinasikan karena ada sesuatu yang tidak masuk akal (V. D. Sugiarto).

Teknik humor (pada data wujud tuturan nomor 11) sebagaimana di atas dengan menggunakan ucapan yang berlebih mengenai klarifikasi permasalahan. Pada segmen tutur di atas pemain 1 (P1) berusaha mengklarifikasi ungkapan pemain $2(\mathrm{P} 2)$ tentang permasalahan yang sedang dialaminya, namun klarifikasi tersebut termasuk memiliki kelucuan sebab tidak masuk akal. Segmen tutur pemain 1 tersebut berisi kedekatan makna dari beberapa kata yang dipakai yaitu kata "habis kontrak" yang diartikan bangunan kontrakan yang habis. Padahal, yang dimaksud kontrak kerja.

\section{c. Peledekan (Insult)}

Teknik humor bahasa (language) dengan peledekan (insult) dalam wacana humor Bajigur TV dilakukan melalui cara menyebut nama barang tertentu. Salah satu pemain berusaha menghina dan meremehkan lawan bicara. Hal tersebut didukung dengan teori teknik humor Berger dalam Sugiarto yang menyatakan bahwa teknik humor bahasa (language) dengan bentuk peledekan (insult) 
yaitu teknik dengan melakukan penyerangan secara terang-terangan, seperti menghina atau meremehkan orang lain (V. D. Sugiarto).

Pergi ke Masjid (video unggahan 7 Mei 2019)

Pemain 2: "Gue mau sholat berjamaah lah ke masjid biar banyak pahalanya."

Pemain 1 : "Alah Lo paling mau nyolong sandal. Iya kan?"

Pemain 2 : "Edah kalau ngomong enggak pakek diayak dulu itu kata-kata, inget ini bulan puasa ini bulan puasa loh Sar."

Pemain 1 : "Sorry Noy lah terus, itu tuh sendal kenapa Lo tenteng-tenteng ? Kayak gembel Lo."

Pemain 2 : "Iya ini Gue mau nuker sendal, soalnya yang Gue ambil kemarin kekecilan."

Pemain 1 : "Aduh dasar keset masjid."

Konteks : pemain 1 dan pemain 2 saling berdialog yang awalnya membahas tentang alasan pemain 2 pergi ke masjid. Kemudian ditutup dengan penjelasan pemain 2 yang menimbulkan gelak tawa yang ternyata alasan pemain 2 pergi ke masjid mau menukarkan sandal hasil mencuri kemarin yang kekecilan.

Teknik humor pada data tersebut dengan menyebut sebutan aneh terhadap lawan bicara. Pada segmen tutur di atas pemain 1 menyebut nama pemain 2 dengan nama barang tertentu atau dengan perbandingan objek. Penyebutan tersebut menggunakan sebuah klausa terikat saja. Hal tersebut bertolak belakang dengan pemahaman kalimat sempurna.

\section{d. Ejekan (Irony)}

Teknik humor bahasa (language) dengan ejekan (irony) dalam wacana humor Bajigur $T V$ dilakukan melalui cara melakukan sindiran secara tidak langsung. Salah satu pemain berusaha menyindir untuk meremehkan lawan bicara. Hal tersebut didukung dengan teori teknik humor Berger dalam Sugiarto yang menyatakan bahwa teknik humor bahasa (language) dengan bentuk ejekan (irony) yaitu teknik menyindir secara halus (V. D. Sugiarto).

Teknik humor (pada data wujud tuturan nomor 5) dengan menggunakan cara membandingkan harga tarif ojek. Pada segmen tutur di atas pemain 1 menyindir secara tidak langsung bahwa harga yang pemain 2 terlalu mahal. Sindiran secara tidak langsung tersebut memakai kalimat pernyataan tanya memerlukan jawaban.

\section{Teknik Humor Logika (Logic)}

Teknik humor logika (logic) dalam Bajigur TV dihasilkan dari pemikiran pemainpemain yang terlibat. Beberapa teknik humor logika (logic) tidak digunakan dalam Bajigur $T V$ hanya beberapa saja yang digunakan. Teknik humor logika (logic) yang digunakan seperti, kekecewaan (disappointment), perbandingan (comparisons), serta kesalahan (mistakes). Temuan teknik humor logic tersebut diuraikan sebagai berikut.

\section{a. Kekecewaan (Disappointment)}

Teknik humor logika (logic) dengan kekecewaan (disappointment) dalam wacana humor Bajigur TV dilakukan melalui cara membuat lawan bicara kecewa terhadap hal yang ditawarkan. Salah satu pemain berusaha memberikan tawaran mengecewakan yang tidak sesuai dengan yang diharapkan. Hal tersebut didukung dengan teori teknik humor Berger dalam Sugiarto yang menyatakan bahwa teknik humor logika (logic) dengan bentuk kekecewaan (disappointment) yaitu teknik penciptaan situasi yang mengarah pada kekecewaan atau tidak sesuai harapan (V. D. Sugiarto).

Teknik humor (pada data wujud tuturan nomor 4) dengan menggunakan cara memberikan tawaran yang membuat lawan bicara kecewa. Pada segmen tutur di atas pemain 2 hanya bisa mengangsur dalam waktu lama sebagai inti dari tuturan yang mengecewakan. Pada segmen tutur tersebut digunakan untuk 
membujuk dan meyakinkan lawan bicara agar bersedia menjual telepon genggamnya dengan cara diangsur, tetapi lawan bicara tidak bersedia melaksanakan atau menerima gagasan tersebut.

\section{b. Perbandingan (Comparisons)}

Teknik humor logika (logic) dengan perbandingan (comparisons) dalam wacana humor Bajigur TV dilakukan melalui usaha memberikan perbandingan yang kontras untuk menyinggung lawan bicara. Hal tersebut didukung dengan teori teknik humor Berger dalam Sugiarto yang menyatakan bahwa teknik humor logika (logic) dengan bentuk perbandingan (comparisons) yaitu teknik humor dengan membandingkan suatu hal yang kontras untuk menghina (V. D. Sugiarto).

Teknik humor (pada data wujud tuturan nomor 2) menggunakan cara memberikan gambaran kontras bagi perokok di akhirat nanti. Pada segmen tutur di atas, pemain 1 memanfaatkan logika untuk memunculkan humor. Tuturan tersebut memakai kalimat perintah. Akan tetapi, tidak memunculkan respon berupa tindakan atau perbuatan sebab kalimat perintah ini begitu memanfaatkan logika. Hal tersebut bertentangan dengan pemahaman kalimat perintah.

\section{c. Kesalahan (Mistakes)}

Teknik humor logika (logic) dengan kesalahan (mistakes) dalam wacana humor Bajigur TV dilakukan melalui memanfaatkan keluguan dan ketidaktahuan lawan bicara. Salah satu pemain berusaha memberikan tawaran pekerjaan yang menguntungkan diri sendiri. Hal tersebut didukung dengan teori teknik humor Berger dalam Sugiarto yang menyatakan bahwa teknik humor logika (logic) dengan bentuk kesalahan (mistakes) yaitu teknik humor dengan memanfaatkan kesalahan karena ketidaktahuan, kelalaian, atau salah paham (V. D. Sugiarto). Sebagaimana cuplikan segmen tutur pemain dalam salah satu tayangan pada Bajigur TV di bawah ini.
Gaji 50 Juta (video unggahan 26 Maret 2019)

(...)

Pemain 2 : "Iya nih Pi Gue masih nganggur aja. Lo kira-kira bisa cariin Gue lowongan kerja enggak?"

Pemain 1: "Ah kebetulan nih, Gue tadi baca lowongan kerja di koran. Ada kerjaan buat Lo. Lumayan gajinya 50 juta, itu pun kalau Lo sukses."

Pemain 2 : "Yang bener Lo Pi kerja apaan tuh emangnya?"

Pemain 1 : "Kerjanya Lo cariin Gue kerja yang gajinya 100 juta. Nanti kalau udah dapet, Lo Gue gaji 50 juta."

Konteks : pemain 1 dan pemain 2 saling berdialog yang awalnya membahas tentang mencari pekerjaan. Kemudian ditutup dengan penjelasan pemain 1 yang menimbulkan gelak tawa yang ternyata sama-sama sedang mencari perkerjaan.

Teknik humor pada data tersebut dilakukan dengan memanfaatkan kesalahan karena ketidaktahuan. Pada segmen tutur di atas pemain 1 memanfaatkan kondisi pemain 2 yang sedang mencari pekerjaan. Tuturan tersebut mengindikasikan teknik humor dengan memanfaatkan kalimat noninti dengan transformasi penambahan atau perluasan.

\section{Teknik Humor Identitas (Identity)}

Teknik humor identitas (identity) dalam Bajigur TV dihasilkan melalui identitas diri pemain yang terlibat. Beberapa teknik humor identitas (identity) tidak digunakan dalam Bajigur TV hanya beberapa saja yang digunakan. Teknik humor identitas (identity) yang digunakan seperti, ejekan dalam bentuk sandiwara atau karangan (Burlesque), pembongkaran (Exposure), serta membuka kedok (Unmasking). Temuan teknik humor identitas (identity) tersebut diuraikan sebagai berikut. 


\section{a. Ejekan dalam Bentuk Sandiwara atau Karangan (Burlesque)}

Teknik humor identitas (identity) dengan ejekan dalam bentuk sandiwara atau karangan (Burlesque) dalam wacana humor Bajigur TV dilakukan melalui memanfaatkan kemalangan lawan bicara. Salah satu pemain menjadikan pemain lagi sebagai korban. Hal tersebut didukung dengan teori teknik humor Berger dalam Sugiarto yang menyatakan bahwa teknik humor identitas (identity) dengan bentuk ejekan dalam bentuk sandiwara atau karangan (Burlesque) yaitu teknik humor dengan menjadikan orang lain sebagai korban humor, memancing orang tertawa melihat kemalangan orang lain (V. D. Sugiarto).

Teknik humor (pada data wujud tuturan nomor 3) menggunakan cara menjadikan kemalangan lawan bicara sebagai objek humor. Pada segmen tutur di atas pemain 2 memanfaatkan kondisi pemain 1 yang samasama sedang tersesat di suatu tempat. Pernyataan tersebut menggunakan kalimat yang langsung membahas pokok bahasan. Hal tersebut tidak sesuai dengan pemahaman kalimat sempurna.

\section{b. Pembongkaran (Exposure)}

Teknik humor identitas (identity) dengan pembongkaran (exposure) dalam wacana humor Bajigur TV dilakukan melalui mengungkapan suatu hal terhadap lawan bicara. Salah satu pemain mengungkapkan tentang dirinya yang tidak mampu melupakan lawan bicara. Hal tersebut didukung dengan teori teknik humor Berger dalam Sugiarto yang menyatakan bahwa teknik humor identitas (identity) dengan bentuk pembongkaran (exposure) yaitu teknik humor dengan mengungkapkan sesuatu tentang diri sendiri (V. D. Sugiarto).

Teknik humor (pada data wujud tuturan nomor 6) menggunakan cara mengungkapkan atau ekspresi yang seolah dilegalkan dengan ungkapan ketidakmampuan untuk melupakan lawan bicara. Pada segmen tutur di atas pemain 1 sedang menggoda pemain 2 .

\section{c. Membuka Kedok (unmasking)}

Teknik humor identitas (identity) dengan membuka kedok (unmasking) dalam WHBTV dilakukan cara berusaha untuk mengungkap maksud sebenarnya lawan bicara melakukan sesuatu. Salah satu pemain berusaha membuka kedok dibalik lawan bicara lakukan. Hal tersebut didukung dengan teori teknik humor Berger dalam Sugiarto yang menyatakan bahwa teknik humor identitas (identity) dengan bentuk membuka kedok (unmasking) yaitu teknik humor dengan membuka kedok, dilakukan oleh orang lain (V. D. Sugiarto).

Teknik humor (pada data wujud tuturan nomor 8) menggunakan cara mengungkap kedok lawan bicara pergi ke masjid. Pada segmen tutur di atas pemain 1 sedang mencari tahu alasan pemain 2 pergi ke masjid. Pada segmen tutur tersebut pamain 2 menggunakan kata-kata yang menutupi makna sebenarnya yaitu "nuker sandal". Makna asli kata tersebut yaitu mengganti barang yang tertukar. Namun, makna yang dimaksud mencuri sandal.

\section{Pemanfaatan sebagai Bahan Ajar}

Materi atau hasil kajian ini dapat dijadikan bahan untuk pembelajaran menulis anekdot di SMA. Dalam hal ini, berkaitan dengan tujuan dibuatnya teks anekdot selain memuat cerita lucu juga terdapat unsur kritikan terhadap pihak-pihak tertentu. Pada proses pembelajaran menulis anekdot dengan menerapkan pendekatan problem based learning, project based learning, atau TPACK (Technology-Pedagogical-Content Knowlegde) dapat memanfaatkan (1) wacana humor secara on linei yang dapat diakses kapan saja dan memiliki kekayaan metabahasa humor sebagai bahan menulis anekdot, (2) wacana ini sebagai bahan permasalahan, proyek, pemunculan kontribusi teknologi dalam penyusunan inti kegiatan pembelajaran dengan menggunakan pendekatan tersebut problem based learning. Proses pembelajaran secara daring 
mapupun luring dapat memanfaatkan acara ini dengan kegiatan analisis wacana humor baik dari segi wujud, prinsip, maupun tekni humor. Hal tersebut lantaran, sebagian besar wacana humor tersebut berisikan kritikan dan sindiran yang dikemas dalam cerita. Kritikan dan sindirian membutuhkan proses berpikir kritis (analisis, evaluatif, dan kreatif).

Tujuan pembelajaran menulis adalah meningkatkan keterampilan berpikir kritis melalui proses dan prosedur analisis wacana kritis pada tahap awal (Wuryaningrum). Dalam kajian penelitian ini, unsur unsur pragmatik baik dari pemerolehan pragmatik, terkait dengan cara dan proses bertutur, dan pemahaman unsur-unsur tuturan dalam memahami maksud dapat dipelajari dari wacana dan analisis WHBTV.

\section{SIMPULAN}

Berdasarkan komponen atau isi, bentuk, dan susunan wacana, wujud WHBT terdiri atas (1) ejekan terhadap pekerjaan, (2) penyebab emosi, (3) memanfaatkan kesusahan, (4) tawaran mengecewakan, (5) tipuan, (6) menggoda wanita, (7) melebih-lebihkan hal sepele, (8) memberikan alasan berubahubah, (9) menjelaskan hal unik tidak masuk akal, (10) olokan tertentu, dan (11) dugaan salah. Wujud ini digunakan sebagai penyampaian dalam berhumor. Dari konteksnya, humor tersebut digunakan untuk menyampaikan ejekan, kritikan, dan sindiran terhadap kebiasaan buruk yang masih sering dilakukan masyarakat.

Prinsip humor WHBT (1) kesepakatan berhumor yaitu legalitas antara pemain yang terlibat atas kebenaran atau ketidakbenaran dalam percakapan tersebut hanya sebatas humor untuk menghibur penonton (2) penggunaan tuturan yang berlebihan (hiperbola (3) penyampaian kritikan dengan ironi, sinisme, dan sarkasme, penyampaian kritikan dan (4) penggunaan kata-kata brutal dalam batas kesopanan untuk memancing senyum dan tawa penonton.
Teknik humor Bajigur TV yang ditemukan yaitu (1) teknik humor bahasa (language) meliputi: (a) omong besar (bombast), (b) pernyataan yang dilebih-lebihkan (exaggeration), (c) penghinaan (insult), (d) ejekan (irony), teknik humor bahasa dipakai sebagai cara menghasikan humor lewat katakata, cara bicara, makna kata, dan akibat dari kata-kata yang dituturkan pemain; (2) teknik humor logika (logic) meliputi: (a) kekecewaan (disappointment), (b) perbandingan (comparisons), (c) kesalahan (mistakes), teknik humor logika juga digunakan untuk memunculkan efek humor dari hasil pemikiran pemain yang terlibat; (3) teknik humor identitas (identity) meliputi: (a) ejekan dalam bentuk sandiwara atau karangan (burlesque), (b) pembongkaran (exposure), (c) membuka kedok (unmasking), teknik humor identitas ini merujuk pada cara berhumor identitas atau ciri khas berhumor pemain.

WHBTV dapat dimanfaatkan atau dikembangkan untuk materi ajar menulis teks anekdot di SMA Kelas X, WHBT dapat digunakan sebagai salah satu altenatif dalam memandu pembelajaran menulis teks anekdot pada jenjang Sekolah Menegah Atas (SMA) Kelas X dengan KD 4.6. Pemanfaatan wacana humor Bajigur TV dalam pembelajaran menulis teks anekdot dapat lebih menumbuhkan semangat siswa, sebab siswa dapat dengan mudah dalam menyusun teks anekdot lewat cerita lucu dan kritikan yang termuat dalam wacana tersebut.

Saran yang ingin diberikan kepada mahasiswa Pendidikan Bahasa dan Sastra Indonesia agar mengkaji hasil penelitian ini untuk bahan diskusi dalam mata kuliah Analisis Wacana. Bagi peneliti lain, yang akan melakukan penelitian sejenis disarankan agar mengembangkan kajian yang lebih mendalam pada gaya bahasa, genre dan ideologi yang terdapat pada wacana humor Bajigur TV. Bagi guru Bahasa Indonesia, hasil penelitian ini disarankan untuk dijadikan sebagai bahan ajar menulis teks anekdot kelas $\mathrm{X}$ semester 1 dengan kompetensi dasar 4.6 yaitu menciptakan kembali teks anekdot 
dengan memerhatikan struktur, dan kebahasaan baik lisan maupun tulis. wujud, prinsip, dan teknik humor yang ditemukan dalam penelitian ini disarakan dapat dijadikan panduan menulis teks anekdot

\section{DAFTAR PUSTAKA}

Arikunto, Suharsimi. Prosedur Penelitian. Yogyakarta: Rineka Cipta, 2002.

Ermawati. "Integrasi Know-Want-Learned-Affect (KWLA) Dalam Pembelajaran Teks Anekdot Sebagai Penguatan Intrapersonal Intellegence." Wacana Akademika (2017): 211-222.

Gumelar, Fajar and Yeti Mulyati. "MEME: Dapatkah Meningkatkan Kemampuan Siswa dalam Menulis Teks Anekdot?" JSSH Jurnal Sains Sosial dan Humaniora (2018): 105-117.

Hartono, Lisa Amelia Anggelina. "Teknik Humor dalam Film Warkop DKI." Jurnal EKomunikasi (2015): 1-10.

Iskandar, Syahril M. "Desain budaya Jawa dalam Opera Van Java." Jurnal Visualita DKV (2010): 1-10.

Lestari, Suci Shinta and Ridho Satrio. "Analisis Isi Pesan Komika Stand Up Comoedy Di Kompas TV." Jurnal Communiverse (CMV) (2019): 1-8.

Listiyorini, Ari. "Wacana Humor dalam Meme Di Media Online Sebagai Potret Kehidupan Sebagaian Masyarakat Indenesia." Litera (2017): 64-77.

Mayora, Syahrul and Tressyalina. "Pengaruh Model Discovery Learning Berbantuan Media Audiovisual Terhadap Keterampilan Menulis Teks Anekdot Siswa Kelas X SMA Negeri 1 Lembah Gumanti Kabupaten Solok ." Jurnal Pendidikan Bahasa dan Sastra Indonesia (2017): 192-200.

Mubarokah, Qoniatul, Djatmika and Sumarlam. "Kata Umpatan Sebagai Humor pada Upacara Pernikahan di Kabupaten Magetan." Prosiding Seminar Nasional Linguistiks dan Sastra (SEMANTIKS) 2019 "Kajian Linguistik pada Karya Sastra". Surakarta, 2019. 663-670.

Musyafa, Nurvani Fitriawati. "Penggunaan Model Picture And Picture dalam Pembelajaran Menulis Cerpen ." Alinea: Jurnal Bahasa Sastra dan Pengajaran (2020): 37-46.

Putry, Melissa Eka Hana. "Peristiwa Tutur dalam Dokumentary Malam Minggu Miko." Arkhais (2016): 15-24.

Saptaningsih, Nur and Vianinda Pratama Sari. "Kritik Sosial dalam Humor Stand Up Comedy Episode "Kita Indonesia" (Kajian Pragmatik)." Seminar Nasional Prasasti II "Kajian Pragmatik dalam Barbagai Bidang". Surakarta, 2015. 324-328.

Sugiarto, Eko. Menyusun Proposal Penelitian Kualitatif: Skripsi dan Tesis. Yogyakarta: Suaka Media, 2018.

Sugiarto, Vania Dewi. "Teaknik Humor dalam Film Komedi yang Dibintangi Oleh Stand Up Comedian." Jurnal E-Komunikasi (2016): 1-12.

Sugiyono. Metode Penelitian Kualitatif. Bandung: Alfabeta, 2018. 
Widyowati, Arini and Endy Pungkas Priambodo. "Hubungan Kepekaan Humor Dengan Stress Kerja Pada Pegawai Balai Karantina Pertanian Kelas 1 Semarang Jawa Tengah." Psikologika (2016): 47-56.

Wiradinata MP, Rochanda, Neneng Titin and Zuhri. "Struktur Teks Dan Unsur Konteks Anekdot Gus Dur Sebagai Altenatif Pemilihan Bahan Pemebelajaran Bahasa Indoensia Di SMA ." Tuturan (2014): 548-566.

Wuryaningrum, Rusdhianti. "The Effectiveness of The Implementation of Critical Discourse Analysis Insurance Advertising in Argumentative Writing Learning for University Students." Retorika (2020): 11-21. 